\title{
Moralitas dan kesadaran terhadap kepatuhan wajib pajak UMKM dengan memanfaatkan fasilitas perpajakan dimasa pandemi Covid-19
}

\author{
Hermi Sularsih*; Soko Wikardojo \\ Prodi Akuntansi, Sekolah Tinggi Ilmu Ekonomi Gempol; Universitas Tribhuwana \\ Tunggadewi Malang \\ *E-mail korespodensi: hermisularsihstieg@gmail.com
}

\begin{abstract}
This research aims to determine the effect of morality and awareness on MSME taxpayer compliance. Based on the data obtained in Gempol District, there are 400 MSMEs. The sample is a collection of subjects that represent the population. The sampling technique used was the purposive sampling method with several criteria: 1) The business is engaged in manufacturing. 2) A business that has been around for more than 5 years. 3) MSMEs that have NPWP. Based on the criteria in determining the number of samples of 255 MSMEs that meet the criteria. So that in this case, the number of samples in the study amounted to 255 MSMEs. Multiple regression analysis tests using SPSS. The results of the study state that significantly the morality variable has a positive effect on MSME taxpayer compliance and awareness variables also affect the compliance of MSME taxpayers.
\end{abstract}

Keywords: Morality, Awareness, Unity of small, Medium micro enterprises.

Abstrak

Riset ini bertujuan untuk mengetahui pengaruh antara moralitas dan kesadaran pada kepatuhan wajib pajak UMKM. Berdasarkan dari data yang didapat di Kecamatan Gempol ada 400 UMKM. Sampel adalah kumpulan subjek yang mewakili populasi. Teknik pengambilan sampel digunakan metode purposive sampling dengan beberapa kriteria adalah 1) Usaha bergerak dalam bidang manufaktur. 2) Usaha yang telah berdiri lebih dari 5 tahun. 3) UMKM yang memiliki NPWP. Berdasarkan kriteria-kriteria dalam penentuan ditetapkan jumlah sampel sebanyak 255 UMKM yang memenuhi kriteria. Sehingga dalam hal ini jumlah sampel dalam penelitian berjumlah 255 UMKM. Uji analisis regresi berganda yang menggunakan SPSS. Adapun hasil penelitian menyatakan bahwa secara signifikan variabel moralitas berpengaruh positif pada kepatuhan wajib pajak UMKM dan variabel kesadaran juga berpengaruh pada kepatuhan wajib wajib pajak UMKM.

\section{Kata kunci: Moralitas, Kesadaran, Kepatuahan Wajib pajak UMKM}

\section{PENDAHULUAN}

Peran pajak sangat penting dalam pembangunan negara sesuai Undang-Undang (UU) No. 28 Tahun 2007 Pasal 1 Ayat 1. Pajak ialah sumbangan wajib kepada negara yang menjadi hutang orang serta badan swasta yang bersifat memaksa tanpa mendapat ganti rugi langsung. Pajak UMKM menjadi salah satu hal perlu harus diperhatikan, pada saat pandemi virus Covid-19 di mana pemerintah mengeluarkan sembilan kebijakan ekonomi ditengah pandemi Covid-19, yaitu Menunda Angsuran hingga Pelonggaran Pajak (Ihsanuddin, 2020), karena pada dasarnya UMKM berdampak (Sularsih , 2018). Apabila wisatawan yang berkunjung berkurang maka omzet UMKM juga akan menurun 
(Abdurrahman Firdaus Thaha, 2020), tentunya hal ini mengganggu perekonomian karena salah satu sektor utama yang berkontribusi terhadap perkembangan ekonomi Indonesia adalah UMKM sehingga perlu mendapat perhatian khusus dari pemerintah saat terjadi pandemi Covid-19, dengan dikeluarkanya berupa fasilitas perpajakan berdasarkan Peraturan Menteri Keuangan No. 44 tahun 2020.

Direktorat Jenderal Pajak (DJP) mengimbau agar pada pemilik UMKM dapat memanfaatkan fasilitas perpajakan yang telah dikeluarkan oleh pemerintah melalui PMK nomor 44 tahun 2020 bagi yang terdampak oleh wabah virus corona. Peraturan ini sebagai upaya hukum bagi UMKM mendapatkan fasilitas pembebasan $\mathrm{PPh}$ PPh-23 Final selama enam bulan. Dalam kurun waktu ini, pemerintah akan menjadi pihak yang akan menyandang PPh PP- 23.

Namun fasilitas yang ditawarkan Pemerintah melalui PMK nomor 44 tahun 2020 baru dimanfaatkan oleh sebagian kecil UMKM. Menurut Dirjen Pajak Suryo Utomo, dari total 2,3 UMKM yang terdaftar sebagai Wajib Pajak (WP), hanya sepuluh persen UMKM yang mengajukan fasilitas perpajakan selama pandemi Covid-19. Tentunya semua tidak terlepas dari kesadaran wajib pajak. Banyak peneliti melakukan penelitian tentang kesadaran wajib pajak yang mampu memberikan pengaruh positif pada kepatuhan wajib pajak (Agustiningsih \& Isroah, 2016; Aswati et al., 2018; Cindy \& Yenni, 2013; Dewi \& Merkusiwati, 2018; Pratiwi \& Setiawan, 2014; Ramadhan, 2017 ; Saputra, 2015; Tene et al., 2017; Tiraada, 2013). Christians, (2014) Isu mengenai integrasi penghindaran pajak dan penghindaran pajak ke dalam satu kerangka untuk menghasilkan satu pesan tentang makna moralitas dalam sikap harus memungut pajak disajikan. Selain kesadaran wajib pajak, ada beberapa peneliti yang melakukan penelitian dalam hal moralitas wajib pajak. Hasil riset menunjukkan moralitas juga berpengaruh pada kepatuhan wajib pajak (Dwianika et al., 2018; Gultom, 2016; Khaerunnisa \& Wiranto, 2015). Namun menurut Ramadhan, (2017) kepatuhan tidak dipengaruhi oleh moralitas wajib pajak.

Penelitian ini menarik untuk diteliti karena selain masih banyaknya UMKM yang tidak memanfaatkan fasilitas yang diberikan oleh pemerintah melalui PMK nomor 44 tahun 2020 juga karena adanya gap penelitian moralitas pada kepatuhan, maka peneliti melakukan penelitian terhadap bagaimana kesadaran dan moralitas mempengaruhi kepatuhan wajib pajak UMKM pada masa pandemi covid-19.

\section{LANDASAN TEORI}

\section{Moralitas pada kepatuhan wajib pajak}

Moralitas perpajakan merupakan motivasi yang muncul dari dalam diri individu untuk melakukan pembayaran pajak (Widodo, 2010: 9). Moralitas perpajakan bisa dibangun lewat partisipasi masyarakat, kepercayaan, dan kebanggaan, serta sistem perpajakan, jika wajib Pajak telah menanamkan rasa bangga, maka dapat termotivasi sebagai warga negara untuk memikirkan kondisi negara ini. Wajib pajak sangat patuh membayar pajak didorong karena adanya perilaku peduli dengan keadaan keuangan negara sehingga partisipasi warga negara yang besar disertai dengan pola pikir yang terbuka untuk memajukn negara (Widodo, 2010: 24-27).

Moral pajak menggambarkan pemahaman batin yang memotivasi untuk memenuhi kewjiban pajak. Pemahaman wajib pajak justru akan dapat meningkatkan kemauan membayar pajak sesuai dengan penghasilan yang diperoleh. Kewajiban moral tidak dipaksakan tetapi diperintahkan dari dalam hati nurani dan moral pribadi. Menurut (Rahayu, 2017) dan (Torgler dan Schneider, 2007) indikator moralitas adalah sebagai berikut: 1). Melanggar etika. 2) Rasa bersalah, 3) Prinsip hidup, 4) Tingkat kepercayaan 
terhadap sistem hukum dan pemerintahan, 5) Persepsi tentang efektivitas sistem perpajakan.

\section{Teori kesadaran pajak pada kepatuhan wajib pajak}

Kesadaran wajib pajak merupakan suatu kondisi akan pengetahuan, pemahaman, dan pelaksanaan ketentuan perpajakan dengan baik dan sukarela, tentunya ini sangat berarti karena mampu membantu wajib pajak guna mematuhi ketentuan perpajakan. Beberapa riset terkait kesadaran dilakukan oleh Adhimatra \& Noviari, (2018) ada pengaruh postif kesadarn wajib pajak pada kepatuhan wajib pajak artinya tingginya keptuhn wajib pajk disebabkn karena tingginya kesadaran wajib pajak. Adhimatra \& Noviari, (2018) kesadaran perpajakan merupakan pelaksanan dan pemahman akan ketentuan perpajakan dengan baik dan sukaren. Indikator dalam riset ini: 1) Mengenali keberadaan peraturan perundang- undangan perpajakan, 2) Mengenali guna perpajakan buat pembiayaan Negeri, 3). Menguasai kalau kewajiban perpajakan wajib dilaksanakan cocok dengan syarat yang berlaku, 4). Menguasai guna perpajakan buat pembiayaan Negeri, 5).Menghitung, membayar, memberi tahu pajak secara sukarela, 6).Menghitung, membayar, memberi tahu pajak dengan benar.

\section{Teori kepatuhan wajib pajak}

Wajib pajak dituntut berpartisipasi aktif menjalankan perpajakannya untuk meningkatkan kepatuhan wajib pajak sesuai dengan perpajakan yang benar. Kepatuhan terhadap kewajiban pajak sukarela merupakan tulang punggung dari sistem penilaian sendiri, serta wajib pajak bertanggung jawab untuk menentukan kewajiban perpajakannya sendiri secara akurat dan tepat waktu dalam membayar dan melaporkan pajaknya. Pengertian kepatuhan wajib pajak menurut Safri Nurmantu yang dikutip oleh (Rahayu, 2017) menyatakan bahwa syarat wjib pajak memenuhi dan melaksanakan semua kewajiban perpajakan disebut dengan kepatuhan pajak. Chaizi Nasucha, (2010) menyatakan bahwa pelunsan terhadap tunggakan dengan mendaftarkan diri, menghitung serta membayarnya ini diartikan sebagai kepatuhan wajib pajak. Berdasarkan Keputusan Menteri Keuangan No.544/ KMK.04/2000, kepatuhan pajak suatu tindakan wajib pajak guna penuhi kewajiban perpajakannya sesuai peraturan perundang-undangan serta perpajakan serta peraturan penerapan yng berlaku di sesuatu negeri”. Kepatuhan pajak adalah suatu kondisi yang merupakan hak untuk memenuhi semua kewajiban perpajakan. Berikut indikator kepatuhan perpajakan menurut Safri Nurmantu, Rahayu, (2010) dan adalah 1). Mendaftar, 2) Melunasi SPT 3) Menghitung dan menghitung pajak 4) Membayar dan melaporkan pajak 5) Menerapkan peraturan perpajakan.

\section{METODE}

\section{Populasi dan sampel}

Populasi mengacu pada kategori luas dari item atau subjek yang memiliki kualitas dan karakter tertentu yang telah ditettapkan oleh penelitian untuk dianalisis dan dipelajari dan diambil kesimpulan. (Sugiyono, 2012: 80). Populasinya pelaku UMKM di Kecamatan Gempol. Berdasarkan dari data yang didapat di Kecamatan Gempol ada 400 UMKM. Sampel adalah kumpulan subjek yang mewakili populasi. Teknik pengambilan sampel digunakan metode purposive sampling dengan beberapa kriteria adalah 1) Usaha bergerak dalam bidang manufaktur. 2) Usaha yang telah berdiri lebih dari 5 tahun. 3) UMKM yang memiliki NPWP. Berdasarkan kriteria-kriteria dalam penentuan ditetapkan jumlah sampel sebanyak 255 UMKM yang memenuhi kriteria. Sehingga dalam hal ini jumlah sampel dalam penelitian berjumlah 255 UMKM. 


\section{HASIL DAN PEMBAHASAN}

Analisis deskriptif stastistik

Deskriptif stastistik bagi setiap variabel yang mana variabel moralitas, kesadaran dan variabel dependenden yaitu variabel kepatuhan wajib pajak UMKM. Jumlah data observasi sebayak 255. Data statistic dari seluruh data statistic variabel yang dipergunaka dalam penelitia ini merupakan berikut ini :

Tabel 1. Deskriptif stastistik

\begin{tabular}{lcccccc}
\hline \multicolumn{1}{c}{ Variabel } & $\boldsymbol{N}$ & Minimum & Maximum & Sum & Mean & Std. Error \\
& & & & & & \\
\hline Moralitas (X1) & 255 & 11 & 25 & 4.686 & 18.38 & .199 \\
Kesadaran (X2) & 255 & 11 & 30 & 5.534 & 21.70 & .263 \\
Kepatuhan Wajib & 255 & 11 & 25 & 4.710 & 18.47 & .208 \\
$\begin{array}{l}\text { Pajak (Y) } \\
\text { Valid N. }\end{array}$ & 255 & & & & & \\
\hline
\end{tabular}

Sumber: Data diolah, 2021

Berdasarka Tabel 1 variabel moralitas terdapat nilai minimum responden yaitu sebesar 11 nilai maxsimum 25, nilai range 14, nilai sum 4.686, nilai mean 18.38 dengan standar deviation 0,199. Pada variabel kesadaran nilai minimum responden 11, nilai maxsimum 30, nilai sum 5534, nilai range 19 dan mean pada variabel kesadaran 21,70 dengan standar deviation sebesar 0,263, sedangkan variabel kepatuhan wajib pajak nilai minimum 11, maximum 25, nillai range 14, nilai sum 4710 dan mean 17,5176 dengan standar devition sebesar 0,208.

\section{Uji validitas}

Validitas instrumen ditentukan dengan mengorelasikan skor yang diperoleh setiap butir pernyatan dengan skor total. Jika rhitung>rtabel, sehingga data dikatakan valid. Perhitungan menggunkan aplikasi software SPSS 2.1.

Tabel 2. Hasil uji validitas

\begin{tabular}{|c|c|c|c|c|c|}
\hline Variabel & Item & $\begin{array}{c}\text { Koefisien } \\
\text { korelasi }\end{array}$ & $r$ tabel & Sig & Keterangan \\
\hline \multirow{3}{*}{ Moralitas $\left(\mathrm{X}_{1}\right)$} & $\mathrm{X} 1.1$ & ,748 & 0,138 & 0,000 & Valid \\
\hline & $\mathrm{X} 1.2$ & ,728 & 0,138 & 0,000 & Valid \\
\hline & $\mathrm{X} 1.3$ & .672 & 0,138 & 0,000 & Valid \\
\hline \multirow{6}{*}{ kesadaran $\left(\mathrm{X}_{2}\right)$} & X1.4 & .573 & 0,138 & 0,000 & Valid \\
\hline & X1.5 & 378 & 0,138 & 0,000 & Valid \\
\hline & $\mathrm{X} 2.1$ &, 558 & 0,138 & 0,000 & Volid \\
\hline & $\mathrm{X} 2.2$ &, 717 & 0,138 & 0,000 & Valid \\
\hline & $\mathrm{X} 2.3$ & ,780 & 0,138 & 0,000 & Valid \\
\hline & $\mathrm{X} 24$ & ,701 & 0,138 & 0,000 & Valid \\
\hline \multirow{7}{*}{ Kepatuhan perpajakan (Y) } & $\mathrm{X} 2.5$ &, 575 & 0,138 & 0,000 & Valid \\
\hline & $\mathrm{X} 2.6$ & 658 & 0,138 & 0,000 & Valid \\
\hline & Y1.1 &, 554 & 0,138 & 0,000 & Volid \\
\hline & Y1.2 &, 746 & 0,138 & 0,000 & Valid \\
\hline & Y1.3 & 735 & 0,138 & 0,000 & Valid \\
\hline & Y1.4 & 635 & 0,138 & 0,000 & Valid \\
\hline & Y1.5 & ,488 & 0,138 & 0,000 & Volid \\
\hline
\end{tabular}

Sumber: Data diolah, 2021 
Nilai korelasi tiap indikator dengan nilai $\mathrm{r}_{\text {tabel }}$ product moment pada $\alpha=5 \%$ dan nilai 255 sebesar 0,138 . Korelasi bertanda positif dan lebih besar ( $>$ )dari $r_{\text {tabel }}$, serta nilai probabilitas lebih kecil $(<) \alpha=5 \%$, sehingga terdapat hubungan signifikan antara skor indikator dengan skor total, sehingga pernyataan keseluruhan dikatakan valid.

\section{Uji reliabilitas}

Konsistensi reliabilitas untuk mengetahui item pernyataan pada kuesioner dengan menggunakan pengujian metode Cronbach's Alpha yang skala alpha Nol (0) sampai dengan 1

Tabel 3. Hasil uji reliabilitas

\begin{tabular}{cc}
\hline \multicolumn{2}{c}{ Reliability Statistics } \\
\hline Cronbach's Alpha & N of Items \\
.856 & 16 \\
\hline
\end{tabular}

Sumber: Data diolah, 2021

Reliabilitas variabel moralitas dan kesadaran pada kepatuhan wajib pajak UMKM mempunyai koefisien reliabilitas 0.856 lebih besar dari 0,06. artinya bahwa nilai "Alpha Cronbach" > lebih besar dari 0,06 , yang artinya instrumen tersebut dinyatakan reliabel atau memenuhi persyaratan.

\section{Hasil uji asumsi klasik}

\section{Uji normalitas}

Hasil Gambar 1 menunjukkan sebaran data (titik) disekitar dan mendekati garis diagonal serta mengikuti arah garis diagonal atau grafik tersebut, sehingga data dapat berdistribusi normal.

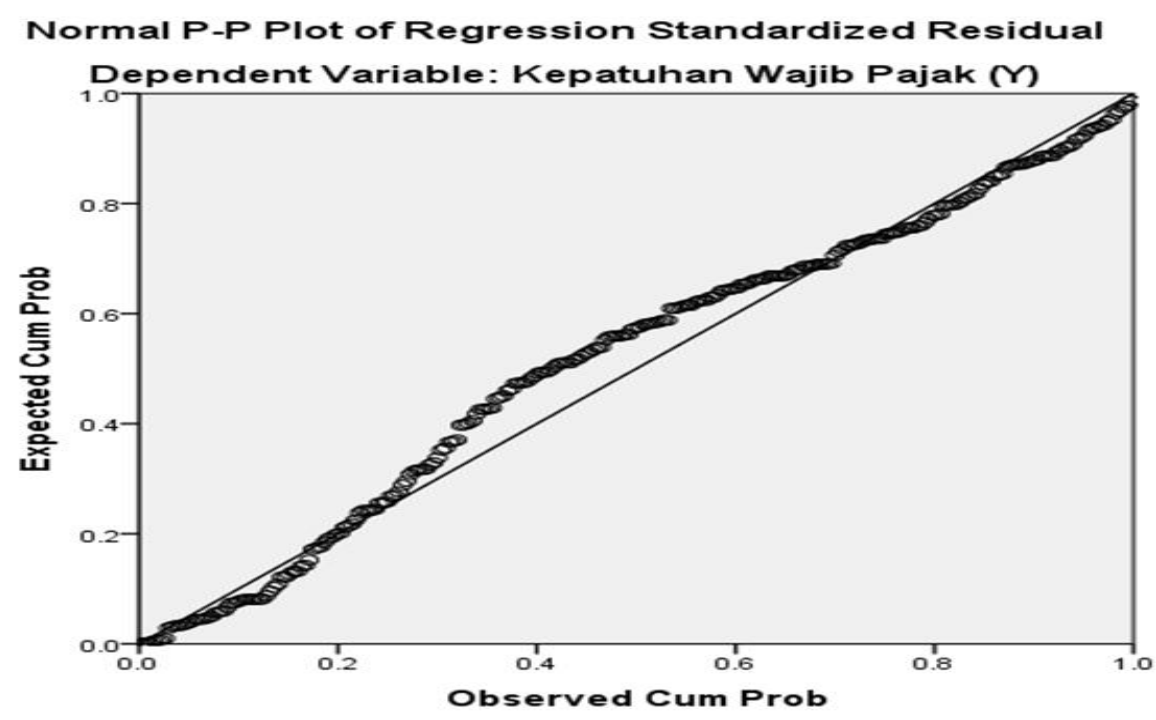

Sumber : Data diolah, 2021

Gambar 1. Normal P-P plot of regression

Berdasarkan Tabel 4 menyatakan hasil uji dengan variabel bebas keseluruhan nilai tolerance moralitas, kepatuhan $>0,10$ dan VIF $<10$ maka penelitian ini tidak ada terjadi gejala multikolinearitas. 
Tabel 4. Hasil uji multikolinearitas

\begin{tabular}{llcc}
\hline Model & \multicolumn{2}{c}{ Collinearity Statistics } \\
\cline { 2 - 4 } & (Constant) & Tolerance & VIF \\
\hline 1 & Moralitas $\left(\mathrm{X}_{1}\right)$ & .369 & \\
& Kesadaran $\left(\mathrm{X}_{2}\right)$ & .369 & 2.708 \\
\hline
\end{tabular}

Sumber; Data diolah, 2021

\section{Uji heterokedastisitas}

Hasil Gambar dibawah menunjukan titik-titik tersebut memecar dengan jelas, dan tersebar ada yang diatas dan dibawah angka nol (0) pada sumbu Y, sehingga mengindikasikan tidak terbentuk heteroskedisitas.

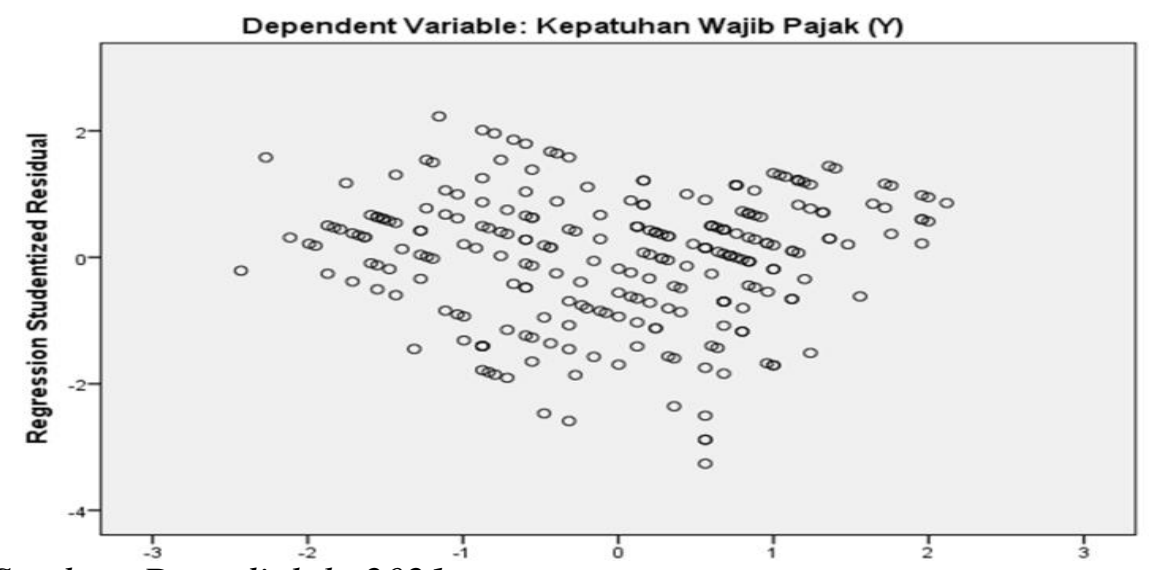

Sumber: Data diolah, 2021

Gambar 2.Grafik scatterplot

Dari Tabel 5. berdasarkan pada hasil analisis tersebut sehingga di simpulkan Durbin-Watson 1,533, nilai DW terletak di antara nilai DW < DL $(1.5895<1>783<$ 1.6457) hasilnya ditolak sehingga disimpulkan bahwa terjadi autokorelasi dalam regresi ini.

Tabel 5. Hasil uji autokorelasi

Model Summary ${ }^{b}$

\begin{tabular}{lll}
\hline Model & Durbin-Watson & \\
1 & & 1.533 \\
\hline
\end{tabular}

Sumber: Data diolah, 2021

\section{Analisis regresi linier berganda}

Dalam uji hipotesis dapat dilakukan dengan menganalisis regresi berganda yang mana akan menguji pengaruh secara empirik untuk mencari hubungan antara variabel independen terhadap variabel dependen.

Tabel 6. Hasil uji regresi linear berganda

\begin{tabular}{lrrrrrrrr}
\hline Model & \multicolumn{2}{c}{$\begin{array}{c}\text { Unstandardized } \\
\text { Coefficients }\end{array}$} & \multicolumn{2}{c}{$\begin{array}{c}\text { Standardized } \\
\text { Coefficients }\end{array}$} & & \multicolumn{2}{c}{ Sig. } & \multicolumn{2}{c}{$\begin{array}{c}\text { Collinearity } \\
\text { Statistics }\end{array}$} \\
\cline { 2 - 5 } & \multicolumn{1}{c}{ B } & Std. Error & \multicolumn{1}{c}{ Beta } & & & Tolerance & VIF \\
\hline (Constant) & 7.014 & .986 & & 7.112 & .000 & & \\
Moralitas (X1) & .241 & .086 & .230 & 2.804 & .005 & .369 & 2.708 \\
Kesadaran (X2) & .324 & .065 & .410 & 4.988 & .000 & .369 & 2.708
\end{tabular}

Sumber: Data diolah,2021 
Berdasarkan tabel 6 hasil dari coefficientsa, dapat dianalisis menggunakan model persamaan regresi linier berganda sebagai berikut :

$$
Y=7,041+0,2411+0,3242+0,986
$$

Hasil dari analisis tersebut dapat diinterpretasikan: 1).Persamaan regresi diketahui nilai konstanta sebesar 10,773, sehingga variabel independen moralitas dan kesadaran dianggap konstan, maka nilai variabel dependen yaitu Kepatuhan wajib pajak UMKM adalah 7,041. 2). Moralitas berpengaruh positif terhadap nilai coefisient dengan nilai 0,241. Setiap mengalami kenaikan nilai variabel moralitas sebesar satu poin, sehingga meningkatkan kepatuhan wajib pajak UMKM sebesar 0,241. 3). Kesadaran pengaruh positif terhadap nilai koefisien sebesar 0,324. Setiap kenaikan nilai variabel kesadaran sebesar satu poin, maka akan meningkatkan kepatuhan wajib pajak sebesar 0,324.

Tabel 7. Hasil uji koefisien determinan $\left(\mathrm{R}^{2}\right)$

\begin{tabular}{rrrr}
\hline Model & R & R Square & \multicolumn{1}{c}{ Adjusted R Square } \\
& & & \\
\hline 1 & $.609^{\mathrm{a}}$ & .371 & .366 \\
\hline
\end{tabular}

Sumber. Data diolah, 2021

Berdasarkan Tebel 7. dapat disimpulkan nilai coefisient determinan atau Adjusted $R$ square $\left(R^{2}\right)$ dengan nilai 0,366 atau $37 \%$. sehingga menunjukkan moralitas, dan kesadaran pengaruh terhadap kepatuhan wajib pajak UMKM sebesar $37 \%$ dan selebihnya $63 \%$ dipegaruhi oleh variabel lain diluar riset.

Tabel 8. Uji hipotesis simultan (Uji f)

\begin{tabular}{|c|c|c|c|c|c|c|}
\hline \multicolumn{2}{|c|}{ Model } & Sum of Squares & Df & $\begin{array}{c}\text { Mean } \\
\text { Square }\end{array}$ & $\mathbf{F}$ & Sig. \\
\hline \multirow[b]{2}{*}{1} & Regression & 1040.891 & 2 & 520.445 & 74.407 & $.000^{\mathrm{b}}$ \\
\hline & $\begin{array}{l}\text { Residual } \\
\text { Total }\end{array}$ & $\begin{array}{l}1762.638 \\
2803.529\end{array}$ & $\begin{array}{l}252 \\
254\end{array}$ & 6.995 & & \\
\hline
\end{tabular}

Sumber. Data diolah, 2021

Berdasarkan Tabel 8 nilai statistik $F_{\text {hitung }}$ sebesar 74.407 dengan tingkat signifikansi 0,000 sedangkan $F_{\text {tabel }} 2,41$. Maka disimpulkan $F_{\text {hitung }} 74.407>F_{\text {tabel }} 2.41$. maka disimpulkan variabel moralitas dan kesadaran secara simultan berpengaruh terhadap kepatuhan wajib pajak UMKM.

Tabel 9. Uji hipotesis parsial (Uji t)

\begin{tabular}{|c|c|c|c|c|c|c|}
\hline \multirow{2}{*}{\multicolumn{2}{|c|}{ Model }} & \multicolumn{2}{|c|}{$\begin{array}{l}\text { Unstandardized } \\
\text { Coefficients }\end{array}$} & \multirow{2}{*}{$\begin{array}{c}\begin{array}{c}\text { Standardized } \\
\text { Coefficients }\end{array} \\
\text { Beta } \\
\end{array}$} & \multirow[t]{2}{*}{$\mathbf{T}$} & \multirow[t]{2}{*}{ Sig. } \\
\hline & & B & Std. Error & & & \\
\hline \multirow[b]{2}{*}{1} & (Constant) & 7.014 & .986 & & 7.112 & .000 \\
\hline & $\begin{array}{l}\text { Moralitas }\left(X_{1}\right) \\
\text { Kesadaran }\left(X_{2}\right)\end{array}$ & $\begin{array}{l}.241 \\
.324\end{array}$ & $\begin{array}{l}.086 \\
.065\end{array}$ & $\begin{array}{l}.230 \\
.410\end{array}$ & $\begin{array}{l}2.804 \\
4.988 \\
\end{array}$ & $\begin{array}{l}.005 \\
.000 \\
\end{array}$ \\
\hline
\end{tabular}

Sumber. Data diolah, 2021

\section{Hipotesis 1}

Hasil uji $\mathrm{t}$ dengan nilai $\mathrm{t}_{\text {hitung }} 2.804$ sedangkan nilai $\mathrm{t}_{\text {tabel }}=0,138$ dan nilai signifikansi $0,000<0,5$, jadi $\mathrm{H}_{0}$ ditolak $\mathrm{H}_{1}$ diterima. Sehingga berdasarkan hasil tersebut 
terbukti variabel Moralitas adanya pengaruh positif serta signifikan pada kepatuhan wajib pajak UMKM.

\section{Hipotesis 2}

Uji $\mathrm{t}$ menghasilkan nilai $\mathrm{t}$ sebesar 4,988, dengan nilai t tabel 1,138 dan nilai signifikansi $0,000<0,05$ yang menunjukkan bahwa $\mathrm{H}_{0}$ ditolak $\mathrm{H}_{2}$ diterima. Berdasarkan hasil temuan tersebut, maka disimpulkan variabel kesadaran berpengaruh positif dan signifikan terhadap kepatuhan wajib pajak UMKM.

\section{Pengaruh moralitas terhadap kepatuhan wajib pajak UMKM}

Moralitas secara parsial berpengaruh positif dan signifikan terhadap kepatuhan wajib pajak, menurut temuan penelitian, dengan memiliki moralitas yang tnggi akan meningkatkan kepatuhan wajib pajak hal ini dikarenakan wajib pajak memahami kewajiban sebagai warga negara sehingga ada rasa takut melanggar etika dari wajib pajak. Selain itu wajib pajak juga merasa bersalah jika tidak memenuhi kewajibannya. Karena itulah bagi wjib pajak merupakan prinsip hidup, moralits yang tinggi juga menunjukkn bahwa masyarkat memiliki tingkat kepercayaan terhadap sistem hukum dan pemerintah sehingga memunculkan suatu persepsi atas efektifitas sistem perpajakan. Hasil riset searah dengan riset yang dilakukan oleh (Dwianika et al., 2018; Gultom, 2016; Khaerunnisa \& Wiranto, 2015) yang mengatakn bahwa ada pengaruh antara moralitas pada kepatuhan wajib pajak UMKM. Berdasarkan hasil riset, maka adanya laporan dri Dirjen pajak bahwa banyak UMKM yang tidak memanfaatkan fasilitas yang diberikan oleh pemerintah, peneliti menganggap bahwa wajib pajak merasa memiliki moralitas sebagai warga negara yang biak dan patuh akan kewajibanya untuk membayar pajak tanpa harus memanfatkan fasiltas tersebut.

\section{Pengaruh kesadaran pada kepatuhan wajib pajak UMKM}

Hasil riset menyatakan bahwa kesadaran secara pensial mempunyai pengaruh positif pada kepatuhan wajib pajak. Penelitian searah dengan riset yang dibuat oleh Adhimatra \& Noviari, (2018) tentang kesadaran Wajib Pajak yang meyakini bahwa peningkatan kesadaran wajib pajak berdampak positif dan signifikan terhadap kepatuhan. Tingkat kepatuhan yang tinggi semakin sadar wajib pajak akan kewajiban perpajakannya. Kesadaran akan kepatuhan wajib pajak tentunya di dasari oleh pemahamam akan peraturan perpajakan sehingga adanya kesadaran tersebut di wujutkan dengan mendaftarkan Diri, melakukan perhitungan pajak, membayar dan melaporkan pajak.

\section{KESIMPULAN DAN SARAN}

\section{Kesimpulan}

Secara pensial moralitas adanya pengaruh positif serta signifikan terhadap kepatuhan wajib pajak UMKM. Secara parsial kesadaran memiliki pengaruh positif dan signifikan pada kepatuhan wajib pajak UMKM. Moralitas dan kesadaran secara simultan memiliki pengaruh positif dan signifikan terhadap kepatuhan wajib pajak UMKM. Fasilatas perpajakan tidak dimanfaatkan oleh pemilik UMKM disebabkan oleh moralitas yang tinggi dan kesadaran wajib pajak serta ketidakpahaman akan fasilitas tersebut.

\section{Saran}

Menurut hasil penelitian dapat disarankan oleh pengkaji sebagai berikut:1).Diharapkan peneliti selanjutnya agar menambahkan variabel penelitian yang 
berbeda sehingga terdapat perbedaan antara penelitian terdahulu dan penelitian selanjutnya, 2). Diharapkan penelitian ini dapat dijadikan referensi dalam penyajian ilmu pengetahuan bagi perpustakaan pengaruh moralitas dan kesadaran terhadap kepatuhan wajib pajak UMKM.

\section{DAFTAR PUSTAKA}

Abdurrahman Firdaus Thaha. (2020). Dampak covid-19 terhadap UMKM di Indonesia. Jurnal Brand. 2(1), 123-130

Adhimatra, A. A. G. W., \& Noviari, N. (2018). Pengaruh kondisi keuangan wajib pajak, kualitas pelayanan fiskus, dan sanksi perpajakan pada kepatuhan wajib pajak orang pribadi di kantor pelayanan pajak pratama Denpasar Timur. E-Jurnal Akuntansi. Vol.25 Oktober, 717-744, https://doi.org/10.24843/eja.2018.v25.i01.p27

Agustiningsih, W., \& Isroah. (2016). Pengaruh penerapan e-filing, tingkat pemahaman perpajakan dan kesadaran wajib pajak terhadap kepatuhan wajib pajak di KPP Pratama Yogyakarta. Nominal, Barometer Riset Akuntansi dan Manajemen. 5(2), 107-122, https://doi.org/10.21831/nominal.v5i2;11729

Aswati, W. O., Masud, A., \& Nudi, T.(2018). Pengaruh kesadaran wajib pajak, pengetahuan pajak, dan akuntabilitas pelayanan publik terhadap kepatuhan wajib pajak kendaraan bermotor (Studi Kasus Kantor UPTB SAMSAT Kabupaten Muna, Jurnal Akuntansi dan Keuangan, 3(1), 27-39

Christians, A. (2014). Avoidance, evasion, and taxpayer morality. Washington University Journal of Law \& Policy. 44 (1): 39-59

Cindy, \& Yenni, M., (2013)., 'Pengaruh kesadaran wajib pajak, kualitas pelayanan fiskus, sanksi perpajakan, lingkungan wajib pajak berada terhadap kepatuhan wajib pajak orang pribadi di Surabaya., Tax \& Accounting Review.1(1), 49-54

Dewi, S. K \& Merkusiwati, N. K. (2018). Pengaruh kesadaran wajib pajak, sanksi perpajakan, E-Filing, dan Tax Amnesty Terhadap Kepatuhan Pelaporan Wajib Pajak;. E-Jurnal Akuntansi. 22(2), 1626-1655, https://doi.org/10.24843/eja.2018. v22.i02.p30.

Dwianika, A., Amin, M. N., \& Setiyahadi, C. (2018). Pengaruh kualitas audit pada hubungan moralitas, budaya dan pelayanan fiskus terhadap kepatuhan wajib pajak. Keberlanjutan. 3(2), 933-949, https://doi.org/10.32493/keberlanjutan.v3i2.y2018. p933-949

Gozali, E., Kamnis, S., \& Gu, S. (2013). Numerical investigation of combustion, and liquid feedstock in high velocity suspension flame spraying process. Surface and Coatings Technology, 228(15 Aug), 176-186, https://doi.org/10.1016/j.surfcoat. 2013.04.026

Gultom, M., F. G (2016). Pengaruh dimensi moralitas pajak terhadap kepatuhan pajak Ilmiah Mahasiswa FEB, 3(1), 58-73

Ihsanuddin. (2020). 9 "Kebijakan ekonomi jokowi di tengah pandemi covid-19" 'penangguhan cicilan hingga relaksasi pajak halaman all - Kompas.com., Kompas;Com. diakses dalam http://kompas.com, Tanggal 12 Juli 2020, Pukul 12.30 WIB

Khaerunisa, I., \& Wiranto, A. (2015). Pengaruh moralitas pajak, budaya pajak, dan good governance terhadap kepatuhan wajib pajak, Jurnal Riset Akuntansi Dan Perpajakan, 1(2), 211-224

Pratiwi, I. G. A. M. A. M..,\& Setiawan, P. E. (2014). Pengaruh kesadaan wajib pajak, kualitas pelayanan, kondisi keuangan perusahaan, dan persepsi tentang sanksi perpajakan pada kepatuhan wajib pajak reklame di Dinas Pendapatan Kota 
Denpasar., Jurnal Akuntansi. 6(1), 139-153

Rahayu, S. K. (2017). Perpajakan konsep dan aspek formal, In Rekayasa Sains: Bandung: Ramadhan, L. Y. (2017). Pengaruh kesadaran, moralitas dan budaya pajak terhadap kepatuhan pajak (Studi Pada UKM Siola Kota Surabaya). Equity. 3(3), 16-33

Saputra, R., (2015). "Pengaruh sanksi, kesadaran perpajakan, dan kualitas pelayanan wajib pajak terhadap kepatuhan wajib pajak bumi dan bangunan" (studi empiris pada wajib pajak kabupaten pasaman); Jurnal Akuntansi, 3(1), 1-19

Sularsih, H. (2018). Dampak Penerapan peraturan pemerintah No 23 Tahun 2018 terhadap peningkatan pajak UMKM di Kota Malang. Jurnal Akuntansi Dan Manajemen. 3 (3), 1-8

Tene, J. H., Sondakh, J., \& Warongan, J. D. L. (2017). Pengaruh pemahaman wajib pajak, kesadaran pajak, sanksi perpajakan dan pelayanan fiskus terhadap kepatuhn wajib pajak, (Studi Empiris Pada Wajib Pajak Orang Pribadi yang Terdaftar di KPP Pratama Manado). Jurnal Riset Ekonomi, Manajemen, Bisnis dan Akuntansi (Jurnal EMBA), 5(2), 443 - 453

Tiraada, T., (2013). Kesadaran Perpajakan,sanksi pajak,sikap fiskus terhadap kepatuhan WPOP di Kabupaten Minahasa Selatan. Jurnal Riset Ekonomi, Manajemen, Bisnis dan Akuntansi (Jurnal EMBA), 1(3), 999-1008 